\title{
Kesadaran Beragama Pelaku Pariwisata di Kawasan Malioboro
}

\author{
Wahyu Amin Arifudin ${ }^{1}$, Nurul Fatihah ${ }^{2}$, Ahmad Echsan ${ }^{3 *}$, Lailatul Maftuhah ${ }^{4}$, \\ Difla Nadjih ${ }^{5}$, Agus Pandoman ${ }^{6}$ \\ $1,2,3,4,5,6$ Universitas Cokroaminoto Yogyakarta \\ *Penulis Koresponden, email: achmadechsan01@gmail.com
}

\begin{abstract}
Abstrak
Penelitian ini mengindentifikasi kesadaran keagamaan para pelaku pariwisata sektor informal peserta program Malioboro Mengaji di Yogyakarta. Penelitian deskriptif kualitatif dengan pendekatan fenomenologis bermanfaat untuk mendapat gambaran dan pandangan para informan secara natural. Data dikumpulkan dengan observasi partisipatif dan wawancara mendalam Sebagian besar informan telah berusia setengah baya yang telah merasakan asam garam kehidupan termasuk segala bentuk penyimpangan terhadap ajaran agama. Perjalananan usia mendorong pencarian kebahagiaan lahir dan batin. Salah satunya dengan belajar mengaji al-Quran. motivasi awal yang melatar belakangi para peserta beragam namun mengalami perubahan seiring dengan partisipasi dalam pelatihan baca Al Quran. Keinginan untuk mewujudkan beban hidup yang lebih ringan dan ketenangan hati dengan rasa bangga karena bisa secara langsung membaca kitab suci Islam yang menjadi pegangan hidupnya.
\end{abstract}

Kata Kunci: Kesadaran beragama, pelaku pariwisata, setengah baya, baca al Quran

\begin{abstract}
This study identifies the religious awareness of informal sector tourism actors participating in the Malioboro Mengaji program in Yogyakarta. Qualitative descriptive research with a phenomenological approach is useful for getting a natural overview and views of informants. The data were collected by participatory observation and in-depth interviews. Most of the informants were middle-aged who had tasted the acid of life including all forms of deviations from religious teachings. The passage of age encourages the search for inner and outer happiness. One of them is by learning the Koran. The initial motivation behind the various participants experienced changes along with participation in the Al Quran reading training. The desire to realize a lighter life burden and peace of mind with a sense of pride in being able to directly read the Islamic holy book that is the guide of his life.
\end{abstract}

Keywords: religious awareness, tourism actors, adult, Quran reading 
Wahyu Amin Arifudin, Nurul Fatihah, Ahmad Echsan, Lailatul Maftuhah,

Difla Nadjih, Agus Pandoman

\section{Pendahuluan}

Proses kesadaran beragama manusia bisa dikategorikan cukup unik dibandingkan dengan aspek-aspek perkembangan yang lain (Rahmat 2007:40). Kesadaran beragama dapat diartikan sebagai aspek mental sebagai hasil dari aktivitas agama (Daradjat 2006), atau dapat diartikan sebagai kepercayaan akan suatu kekuatan yang ghaib, di mana kekuatan tersebut menimbulkan cara hidup tertentu (Nasution 1985) Kesadaran itu dimulai saat seseorang sadar akan dirinya sendiri secara alami, tanpa merasa dirinya diciptakan secara instan sehingga menyebabkan persepsi awal berupa pengalaman mistis, bahwa dirinya merupakan hasil ciptaan (Giussani 1998)

Ancok dan Suroso (2005) menunjuk seseorang yang sadar beragama dalam beberapa dimensi sebagai indikator, antara lain; dimensi keyakinan, dimensi peribadatan, dimensi penghayatan, dimensi pengetahuan, dan dimensi pengamalan. Semuanya tercakup dalam aspek kognisi, afeksi dan konasi. kognisi terkait dengan akal pikiran manusia sebagai potensi untuk mendorong seseorang berbuat baik dan menghindari perbuatan buruk. Afeksi berhubungan dengan perasaan atau emosi. Sementara konasi berkoneksi dengan tindakan atau pengamalan keagamaan (Munirah dan Ladiku 2018; Sudrajat n.d.).

Kesadaran dan tindakan beragama itu didorong dengan motivasi. Dorongan atau kekuatan dari jiwa keagamaan yang mengarahkan aktivitas dari manusia untuk melaksanakan ajaran agamanya (Hakiki dan Cahyono 2015; Hamali 2017). Dister (1982) mengurai beberapa motivasi yang mendasari seseorang untuk menganut agama antara lain; frustasi, takut, kesusilaan dan intelektualitas. Kondisi frustasi muncul saat kekecewaan seseorang disebabkan kebutuhan yang tidak dapat terpenuhi atau tujuannya tidak dapat tercapai (Kartini dan Andari 1996). Salah satu cara mengatasi frustasi dengan berpaling pada tingkah laku keagamaan (Mulyadi 2015). Hal demikian banyak ditemukan dalam perilaku zikir yang dimaksudkan untuk memberikan ketenangan dalam ajaran agama Islam (Bisri 2017).

Apabila di usia lanjut, aspek perkembangan manusia yang lain semakin menurun, tetapi pertumbuhan agamanya cenderung meningkat. 
Hasil demikian seperti yang pernah diteliti oleh Hidayat dalam Subandi (1995) tentang kesadaran agama para wanita lanjut usia pada tahun 1983. Di usia dewasa, keberagamaan seseorang telah masuk dalam perspektif yang luas berdasar atas nilai-nilai yang diyakini. Mereka berusaha sepenuh hati dalam melakukan pendalaman pengertian sampai perluasan wawasan tentang ajaran agama yang dianutnya. Ketaatannya terhadap nilai-nilai yang diyakini diwujudkan dalam praktek hidup keseharian secara interpersonal dan intrapersonal (Febrianingsih dan Merdekasari 2018). Agama untuk pribadi dewasa telah meresap sebagai sikap hidup (Mustafa 2016).

Penyebaran agama yang menyadarkan menjadi bagian yang teka terpisahkan agar bisa mencapai sasaran. Hal itu bisa dilihat dari penelitian Heri di Lapas Kelas IIb Anak Wanita Tangerang. Kegiatan keagamaan di situ telah dilakukan rutin dalam mingguan dengan pengajar yang datang secara sukarela, namun belum memberikan dampak positif sehingga jiwa para penghuninya belum tersentuh (Heri 2019).

Penelitian berlokasi di Malioboro ini berusaha mengindentifikasi kesadaran keagamaan para pelaku pariwisata sektor informal di Kawasan Maliboro Yogyakarta. Mereka telah mengikuti pelatihan mengaji dalam program Malioboro Mengaji yang diselenggarakan oleh LDPM UCY bekerja sama dengan para mitra lembaga dan pribadi. Dibandingkan dengan penelitian Rahayu tentang pendidikan Quran usia dewasa (Rahayu et al. 2019), program ini lebih terbuka bagi siapa saja namun disasarkan kepada mereka yang sedang belajar awal. Eksplorasi selanjutnya ditujukan motivasi dan perubahan yang dirasakan oleh peserta pelatihan

\section{Metode}

Penelitian ini menggunakan metode penelitian deskriptif kualitatif. Pendekatan fenomenologis sangat tepat digunakan dalam penelitian ini karena dalam penelitian kualitatif gejala itu bersifat holistik (menyeluruh, tidak dapat dipisah-pisahkan) secara natural. Peneliti kemudian tidak akan menetapkan penelitian hanya berdasarkan variabel penelitian, tetapi keseluruhan situasi sosial yang diteliti meliputi aspek tempat (place), pelaku (actor), dan aktivitas (activity) yang berinteraksi secara sinergis (Sugiyono 
Wahyu Amin Arifudin, Nurul Fatihah, Ahmad Echsan, Lailatul Maftuhah, Difla Nadjih, Agus Pandoman

2013:207). Pengumpulan data banyak menggunakan observasi partisipatif dan wawancara mendalam dari informan terpilih dari peserta pelatihan mengaji pada program Malioboro Mengaji. Para peneliti terlibat aktif sebagai pembina dan tutor dari pelatihan mengaji tersebut.

Gambar 1

Pembukaan Malioboro Mengaji

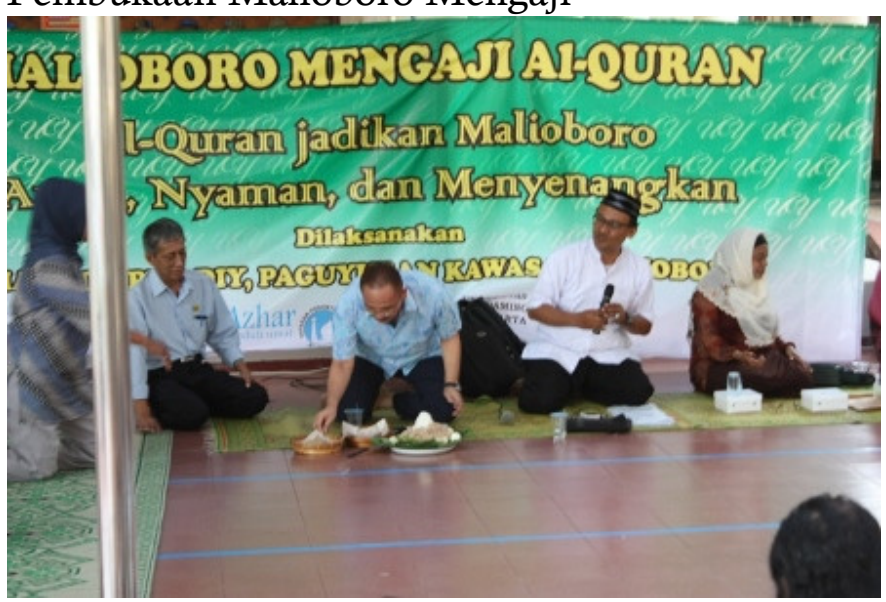

Gambar 2

Sebagian Peserta Malioboro Mengaji

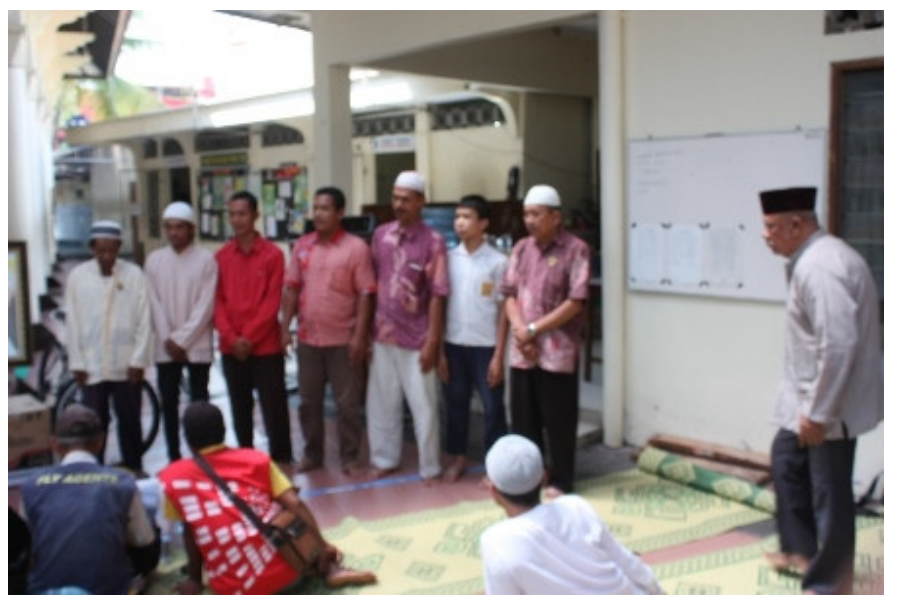

Gambar 3

MahasiswaTutor Malioboro Mengaji

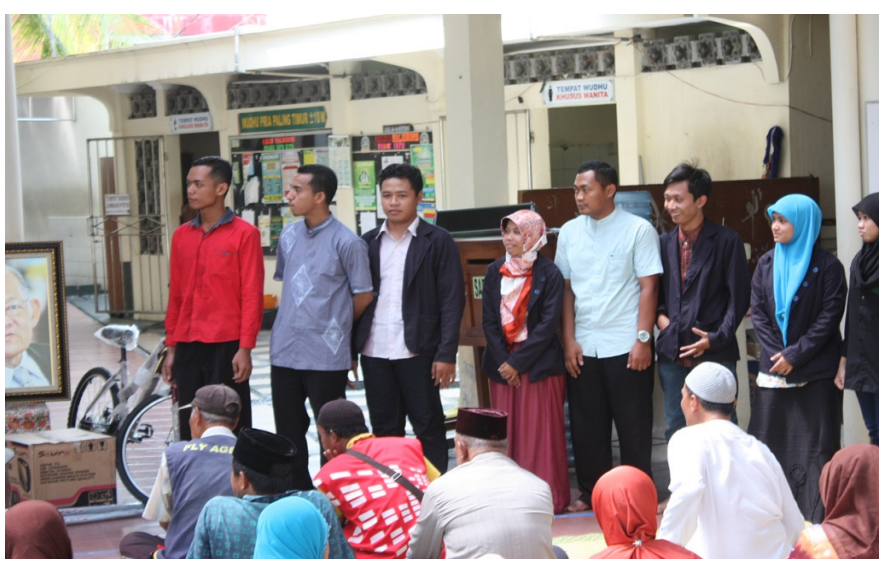




\section{Deskripsi dan Pembahasan}

Informan dalam penelitian ini adalah tukang becak, pedagang kaki lima (PKL) dan pasar, dan pemandu wisata yang telah berusia lebih dari setengah baya yang biasa melayani para turis di kawasan Malioboro Yogyakarta. Mereka juga peserta pelatihan membaca Al-Qur'an di Masjid DPRD Malioboro Yogyakarta dalam program Maliboro Mengaji. Nama dari para informan bukan yang sebenarnya dan disamarkan).

Pelaku 1

Biodata pelaku sebagai berikut;

Nama lengkap

Status dalam keluarga

Jumlah anggota keluarga

Alamat

Pekerjaan

Tempat, Tgl.lahir

Pendidikan terakhir
: Salim

: Kepala Keluarga

: 3 (tiga)

: Magelang

: PKL

: Magelang,15-04-1970

: SMA

Deskripsi tentang kesadaran keberagamaan Pelaku 1

Pak Salim dibesarkan di kota Bandung, bisa berbahasa Jawa dan Sunda. Mendapatkan istri orang Yogyakarta yang bekerja di catering. Di Malioboro, Pak Salim berjualan assesoris. Karena belum punya lapak tetap, tempat dagangannya selalu berpindah-pindah. Penghasilannya juga menjadi menentu.

Salim lahir dari keluarga dan lingkungan masyarakat muslim. Namun, masyarakat lingkungannya tidak banyak melakukan kegiatan keagamaan, kecuali ibadah hari besar Islam dan Yasinan. Pengetahuan agama hanya dari ceramah dan peraktek keagamaan keluarga dan masyarakat. Dia belum pernah belajar membaca Al-Qur'an ,meski beberapa surat pendek sudah dia hafal dan mampu menyebut rukun iman dengan benar. Dengan pengetahuan 
Wahyu Amin Arifudin, Nurul Fatihah, Ahmad Echsan, Lailatul Maftuhah,

Difla Nadjih, Agus Pandoman

agama yang terbatas, selain beribadah saat hari besar Islam, Pak Salim juga rajin menjalankan shalat 5 waktu.

Pengalaman religi yang dia alami adalah kisah tentang istrinya. Tiga tahun yang lalu dia menyangka istrinya sudah gila karena setiap, saat menyapu halaman rumah yang ia tempati, selalu menangis sambil memanjatkan do'a "Ya, Allah, duh pengeran nyuwun paringii rizki kangge mbangun griyo" (Ya Allah, Tuhanku mohon berikan rizqi untuk membangun rumah). Hal tersebut dilakukan istrinya setiap hari. Pak Salim sempat mengingatkan istrinya supaya menggunakan akal sehatnya, darimana uang untuk membangun rumah, sedangkan kondisi pekerjaan dan penghasilan tidak menentu. Tapi tak disangka, suatu hari istrinya menelpon dan memberi kabar, istrinya mendapat undian Rp. 200.000.000 dari Bank Artha tempat dia menabung. Sungguh peristiwa 3 tahun yang lalu itu tak terlupakan dan menjadi pengalaman religi baginya dan istri. Begitu cepat Allah mengabulkan do'a istrinya. Semula Pak Salim sulit mempercayai cerita istrinya dan diapun bergegas pulang dan kenyataanya memang benar, istrinyapun berujar "iyo to mas, nek nyuwune tememen karo sing kuwoso iki yo diparingi" ("benar kan Mas, kalau kita meninta dengan sungguh-sungguh pada Yang Kuasa, ya diberi”.pen). Maka dibangunlah rumah yang mereka tempati sekarang.

Pembahasan Pelaku 1

Meskipun berasal dari keluarga muslim namun pengetahuan agama pelaku masih sangat kurang. Implementasi pelaku terhadap aktivitas keagamaan baru sebatas sholat lima waktu dan ibadah pada hari-hari besar Islam. Pelaku memiliki motivasi yang kuat untuk mengikuti pelatihan membaca Al-Qur'an karena dorongan ingin mengikuti acara Yasinan di kampungnya. Keikut sertaan Pak Salim dalam pelatihan membaca Al-Qur'an membahagiakan dirinya, karena selain sudah mulai bisa membaca Al-Qur'an juga lebih merasakan ketentraman batin dan sekarang tak lupa menyertakan keikhlasan dalam setiap langkahnya. Begitu pula dalam mencari rizki halal, semata ibadah kepada Allah.

\section{Pelaku 2}

\section{Biodata pelaku sebagai berikut:}


Nama

Status dalam keluarga

Jumlah anggota keluarga

Alamat

Pekerjaan

Tempat, Tgl.lahir

Pendidikan terakhir
: Ecan

: Kepala Keluarga

: 4

: Bantul

: Pemandu Wisata (tourguide)

: Yogyakarta, 07-07-1959

: SMA

Deskripsi tentang kesadaran keberagamaan Pelaku 2

Pak Ecan terlahir dari keluarga muslim, ayah asli Yogyakarta dan ibunya asli Bogor. Sekolah SD di Bogor kemudian melanjutkan SMP dan SMA Al-Ma'arif di Yogyakarta. Dibesarkan di daerah Sosrowijayan tempat segala macam hiburan dan para wisatawan menginap. Bahkan dia menyebutnya kampung maksiat, yang di tahun 80 -an tempat sarang narkoba, minuman keras dengan segala bentuk permainan judi. Kakeknya adalah orang berada yang pada zamannya termasuk orang terpandang dan memiliki Hotel pertama di Yogyakarta diresmikan tagl.04-04-1920, di daerah Sosrowijayan dengan nama hotel "ASIATI".

Pengalaman hidup Pak Ecan sangat berwarna, sempat keluar masuk tempat kerja karena selalu tidak fokus dengan pekerjaannya. Pernah juga Pak Ecan kuliah di Fakultas Hukum berhenti di semester dua saja karena lebih tertarik gemerlapnya kehidupan di luar.

Salah satu pengalaman berharga yang diingat Pak Ecan adalah saat ia dibangku kuliah. Saat itu dia punya tugas kuliah yang harus di fotokopi. Sebelum berangkat, Pak Ecan meminjam uang pembantunya sebesar Rp. 1.000,- untuk fotokopi. Namun saat yang bersamaan, seorang gurunya meninggal dunia dan dia takziyah. Setiba di masjid dimana jenazah sang guru di sholatkan, Pak Ecan menyumbangkan uangnya itu ke kotak masjid yang saat itu sedang dalam renovasi. Pak Ecan melakukannya begitu saja tanpa berfikir bahwa ia harus fotokopi tugas kuliahnya. Selang 3 hari kemudian, dia bertemu seorang calon mahasiswa dari Palembang yang meminta tolong padanya untuk mempekenalkan dengan seseorang yang bisa merekomendasikan masuk kuliah di salah satu perguruan tinggi swasta. 
Wahyu Amin Arifudin, Nurul Fatihah, Ahmad Echsan, Lailatul Maftuhah,

Difla Nadjih, Agus Pandoman

Sebagai rasa syukur diterima kuliah di perguruan dimaksud, Pak Ecan diberi uang dua juta, suatu pengalaman tidak terlupakan dan dia meyakini itu balasan terhadap uang yang ia sumbangkan ke masjid dengan ikhlas.

Dari sisi pengetahuan agama, dia mampu menyebutkan rukun Iman. Pengetahuan agama diperolehnya dari bangku sekolah SMP dan SMA, juga dari para ustadz/kyai ketika khotbah. Pak Ecan tidak pernah belajar khusus mengaji, pengetahuan agama ataupun membaca Al-Qur'an.

Keinginannya untuk lebih dekat dengan agama setelah kelahiran anak pertamanya; berhenti minum, berjudi bahkan berhenti merokok sejak 2001. Terakhir merokok malam tirakatan 17 agustus 2001 itupun hanya satu batang rokok. Pak Ecan juga mengaku sudah menjalankan sholat lima waktu.

Bergabung dalam pelatihan membaca Al-Qur'an, menentramkan batinnya. Problem hidup terutama terkait ekonomi, penghasilan tidak menentu sering membuat hati dan perasaan galau tapi sekarang terasa lebih santai tidak ngoyo dan rizki lancar. Ingin menimba ilmu agama lebih banyak. Sebagai kepala keluarga banyak hal dia hawatirkan terhadap keluarganya tapi dengan kekuatan doa dan sikap ikhlas hal tersebut menentramkan batinnya.

Pembahasan pelaku 2

Dengan latar belakang lingkungan yang kurang mendukung, Pak Ecan merasa hidupnya tidak tenang. Pengalaman berjudi, minum minuman keras, dan merokok membuat kehidupan Pak Ecan tidak pernah tenang. Keinginannya untuk memperbaiki kehidupan dan menjadi kepala keluarga yang baik, mendorongnya untuk bersikap dan berbuat baik dengan meninggalkan kebiasan buruknya, termasuk keinginannya belajar agama.

Tidak banyak yang bisa dilakukannya untuk mendidik anak-anaknya dalam beragama karena keterbatasan pengetahuan agama, bahkan putra pertamanya yang lulus SMA tidak lanjut kuliah, berpindah-pindah tempat kerja dan kebiasaan minuman keras. Berharap kecelakan yang menimpa anak sulungnya beberapa waktu yang lalu (dalam kondisi mabuk) bisa membuatnya jera dan tidak mabuk lagi.

Pembawaan Pak Ecan tenang, berpenampilan semakin bersih dan rapi dari hari ke hari. Latar belakang pernah sekolah agama dan dan keuletannya 
dalam belajar memudahkan para pendamping pelatihan untuk meningkatkan kualitas bacaannya atau tajwidnya. Pengetahuan agama lebih dibanding teman-temannya sesama peserta pelatihan karena pernah mengenyam pendidikan agama di sekolah. Pak Ecan termasuk peserta yang aktif dan terkadang peserta yang lain meminta tolong untuk dibantu membetulkan bacaannya. Bergabung di kelompok Pelatihan membaca Al-Qur'an menambah keyakinannya untuk lebih mendekatkan diri pada Allah melalui membaca Al -Qur'an untuk meraih kebahagiaan.

Pelaku 3

Biodata pelaku sebagai berikut;

Nama

Status dalam keluarga

Jumlah anggota keluarga

Alamat

Pekerjaan

Tempat, Tgl.lahir

Pendidikan terakhir
: Wahid

: Kepala Keluarga

: 3

: Yogyakarta

: Tukang Becak

: SMK otomotif

Deskripsi tentang kesadaran keberagamaan Pelaku 3

Berasal dari keluarga dengan tingkat ekonomi yang tergolong rendah, Pak Wahid yang berasal dari NTB. Setamat SD tanpa ijin orang tuanya, dia pergi mengadu nasib ke Jayapura, Papua. Dalam perantauan itu dia bertemu dengan keluarga muslim asal Kebumen Jawa Tengah yang kemudian menjadi keluarga angkatnya. Bersama keluarga angkatnya itu dia disekolahkan SMP. Setelah menyelesaikan studinya itu Wahid memutuskan untuk ikut dengan keluarga angkatnya pulang kampung ke Jawa. Hingga akhirnya dia sampai di kota Semarang.

Perantauannya ke Semarang tanpa tujuan, dan tanpa tempat yang jelas untuk bernaung. Dia hidup menggelandang di Semarang selama beberapa tahun hingga akhirnya dia memutuskan untuk mencoba mengadu nasib ke ibukota. Di Jakarta selama beberapa tahun menjadi kernet angkutan umum. Tidak hanya bekerja, Pak Wahid juga berkesempatan untuk melanjutkan 
Wahyu Amin Arifudin, Nurul Fatihah, Ahmad Echsan, Lailatul Maftuhah,

Difla Nadjih, Agus Pandoman

studinya ke jenjang STM jurusan mesin atas kebaikan supir angkot di mana dia bekerja.

Beberapa tahun bekerja di Jakarta ternyata membawa pengaruh yang kurang baik bagi Pak Wahid. Kehidupan jalanan, pergaulan yang akrab dengan minuma keras dan perjudian teryata juga menjadi pengalaman hidupnya selama di Jakarta. Pernikahannya dikaruniai dua orang anak, Ketidak harmonisan dalam rumah tangga menyebabkan Pak Wahid memutuskan untuk pindah ke Yogyakarta dengan harapan memperoleh kehidupan yang lebih baik. Dia pergi meninggalkan istri tanpa status perceraian yang jelas dan juga kedua anaknya.

Setibanya di Yogyakarta, Pak Wahid kembali hidup menggelandang hingga dia memutuskan menjadi tukang becak. Di kota ini dia bertemu dengan perempuan beragama katolik yang kemudian menjadi muallaf, hidup bersama tanpa ikatan perkawinan yang syah, dikaruniai seorang putra, Saat ini berusia lima tahun. Berhijrah ke Yogyakarta ternyata tidak merubah gaya hidup Pak Wahid sebelumnya yakni minum-minuman keras dan berjudi. Saat istrinya mengandung, Pak Wahid bernadzar untuk berhenti minum-minuman keras dan berjudi jika anaknya lahir laki-laki. Dia bertekad untuk menjadi orang yang lebih baik. Saat anaknya lahir dan berjenis kelamin laki-laki,Pak Wahidpun memenuhi nadzarnya, dia berhenti minum-minuman keras dan berjudi.

Penampilan Pak Wahid sehari-hari sungguh mencerminkan pengalaman hidupnya. Rambut dikucir, lengan bertato, dan sederet anting di telinganya. Meski dengan penampilan demikian, dia tetap berani masuk masjid untuk shalat meski pernah mendapat teguran dari peserta jamaah shalat jumat tentang penampilannya. Teguran ini sebelumnya bisa berakhir dengan adu fisik. Namun setelah Pak Wahid bergabung dalam Pelatihan Belajar Membaca Al-Qur'an, dengan ringan Pak Wahid menjawab teguran dengan mengatakan "mang mikir awak sampean dewe ampun mikir liyan" (anda fikirkan saja diri anda sendiri, tidak usah memikirkan orang lain, pen.) dan diapun melanjutkan shalat. Kehidupan keluarga dirasakan lebih harmonis karena sudah jarang diwarnai pertengkaran yang biasa berujung 
penganiayaan secara fisik terhadap istrinya. Bekerja terasa lebih ringan, aliran rizki lebih lancar.

Pembahasan Pelaku 3

Pertama kali Pak Wahid bergabung di Kelompok belajar membaca AlQur'an, mengesankan dia seorang preman, berbusana lusuh dengan bau khas jalanan, kurus terkesan kurang sehat. Posisi duduk di barisan paling belakang. Ketika diperlihatkan huruf arab tidak semua mampu diingat. Kemauan datang di majlis ilmu atau pelatihan membaca Al- Qur'an memberikan harapan terlepas dari niatan atau motif kedatangannya. Saat disampaikan bahwa apabila yang hadir sebagai peserta pelatihan karena ikhlas mengharap ridha Allah, maka huruf arab yang sebentar lagi akan ditayangkan akan mampu diingat karena huruf tadi tidak mau keluar dari kepala orang shalih. Reaksi yang teramati mereka menjadi antusias menunggu penayangan huruf arab atau huruf yang ada di dalam Al-Qur'an hebatnya lagi mereka dengan cepat bisa beradaptasi dalam proses pembelajaran, mereka terseyum puas tak terkecuali Pak Wahid. Pada pertemuan pertama hampir semua peserta terkecuali Pak Saeran mampu menghafal semua huruf yang ada di empat kata lembaga (enam belas huruf). Kedatangan berikutnya Pak Wahid sudah mulai memposisikan duduk di barisan kedua. Begitu seterusnya dan diapun terkadang dibarisan depan. Pak Wahid dengan mudah menghafal semua huruf beserta perubahan bunyinya.

Kini Pak Wahid sudah berubah, dia terlihat bersih dengan pakaian yang selalu rapi meski tetap menggunakan anting-anting, rambut panjang berpeci serta asesoris yang bergelantungan. Kemampuan membaca huruf arabnya semakin bagus. Sejak mengikuti pelatihan, kondisi keluarga semakin baik, Pak Wahid tidak lagi kasar dengar istrinya. Sebelumnya, istri Pak Wahid sering lari ke rumah tetangga yang disegani Pak Wahid untuk mengadukan kekasaran suaminya.

Pengakuannya bahwa sekarang dia lebih bisa mengatur emosinya dan lebih santun terhadap keluarga, teman dan penumpang becaknya dituturkan juga oleh temannya. Hingga saat bergabung dengan pelatihan membaca A1Qur'an ini,Pak Wahid terbuka dengan masalah pribadinya itu dan fasilitator 
Wahyu Amin Arifudin, Nurul Fatihah, Ahmad Echsan, Lailatul Maftuhah,

Difla Nadjih, Agus Pandoman

menyambut baik serta akhirnya menfasilitasi Pak Wahid untuk melakukan pernikahan secara agama dengan perempuan yang telah melahirkan anak biologisnya itu. Pernikahan secara resmi sedang dalam proses pengurusan dengan instansi terkait.

Pelaku 4

Nama

: Latul

Status dalam keluarga

: Kepala keluarga

Jumlah anggota keluarga

: 4 (empat)

Alamat

: Bantul

Pekerjaan

: Pedagang pasar

Tempat, Tgl.lahir

: Ngawi, 19-06-1960

Pendidikan terakhir

: SMP

Deskripsi tentang kesadaran keberagamaan Pelaku 4

Pak Latul panggilan akrabnya, terlahir dari keluarga dan lingkungan muslim tapi rata-rata tidak menjalankan kewajiban agama seperti shalat dan mengaji. Masa remajanya dia habiskan waktu untuk mendapatkan gemblengan mental dari tokoh Muhammadiyah bernama Pak Bambang, memperkuat barisan muslim dari gangguan orang-orang usil terhadap mereka.

Pendidikan mental yang dilakukan Pak Bambang membawa pengaruh pada pembentukan karakter dirinya menjadi orang yang berani bersikap tegas pada kondisi tertentu. Seperti ketika tahun 1999 saat sosialisasi rencana relokasi pedagang kaki lima di Malioboro, diapun dengan berani menanyakan "siapa yang punya ide relokasi, eksekutif apa legislatif", dalam forum tersebut tidak ada yang bisa menjawab. Dan keesokan harinya dia kumpulkan para pedagang, dikordinir untuk membentuk wadah perjuangan bersama sehingga lahirlah "Paguyuban Pasar Sore", dia yang ditunjuk jadi ketua. Berkat perjuangan bersama inilah, relokasi tidak dilanjutkan.

Pemahaman tentang agama kurang, namun semangat membela agama sangat tinggi. Ketika diminta untuk mengucap kalimah syahadat, diucapkannya dengan benar, dia hafal dan faham tentang rukun Iman dan rukun Islam. Setelah bisa membaca Al-Qur'an dan mempertahankan prilaku 
istiqomah berencana menunaikan ibadah haji supaya ketika pulang haji tidak berprilaku yang tidak sesuai. Pengetahuan agama didengar dari para khotib, juga dari keluarga istrinya. Meskipun besar keinginannya untuk bisa membaca Al-Qur'an, tapi dia tidak senang belajar dengan anak atau istrinya.

Shalat 5 waktu dia jalankan sejak kecil begitu juga puasa Ramadhan. Disamping mengeluarkan zakat fitrah di bulan Ramadhan, dia juga membagikan shadaqah karena dia tidak mengerti tata-cara zakat. Istri Pak Latul seorang santriwati pandai mengaji, begitu juga kedua putrinya. Putri yang pertama sarjana ekonomi dan sudah bekerja di hotel. Putri keduanya masih duduk di bangku SMP. Kondisi inilah antara lain yang memotivasi Pak Latul untuk belajar membaca Al-Qur'an, selain juga keinginannya untuk beribadah haji dengan sempurna. Meskipun besar keinginannya untuk bisa membaca Al-Qur'an, namun dia merasa malu belajar dengan anak istrinya. Ajakan Pak Jarwo untuk mengikuti pelatihan membaca Al-Qur'an, disambut dengan semangat. Karena dia tidak tahu, orang seperti dirinya, harus belajar dimana. Pak Latul satu satunya peserta yang menolak ketika diberi uang transport. Dia merasa lebih damai dan lebih dekat dengan Allah ketika dia berjuang untuk bisa membaca kalamullah ini. Manfaatnya sangat besar bagi ketenangan batinnya.

Pembahasan Pelaku 4

Pak Latul termasuk peserta pelatihan yang aktif dengan penampilan yang rapi berpeci dan terkesan sangat serius. Memulai latihan dengan belum mengenal sama sekali huruf arab dan dia bisa mencapai target pembelajaran. Memperoleh pengetahuan agama dan menjalankan agama setelah beliau menikah dengan keluarga terbilang santri. Motivasi mengikuti pelatihan karena berharap bisa beribadah haji dengan sempurna. Dia merasa memproleh ketentraman batin mengikuti pelatihan ini.

\section{Kesimpulan Dan Saran}

Sebagian besar informan berasal dari keluarga dengan latar belakang muslim yang tidak menjalankan syariat agama dengan beragam lika liku kehidupan, bersentuhan dengan perjudian, minuman keras, pergaulan bebas dan segala bentuk penyimpangan terhadap ajaran agama. Perjalananan usia 
Wahyu Amin Arifudin, Nurul Fatihah, Ahmad Echsan, Lailatul Maftuhah,

Difla Nadjih, Agus Pandoman

ternyata tidak menutup kemungkinan bagi mereka untuk menyadari dan mencari jalan terang menuju kebenaran agama untuk membebaskan diri dari belenggu ketidak pastian dalam mencari kebahagiaan lahir dan batin. Hal ini tercermin dari keaktifan mereka menghadiri pelatihan serta antusiasme mereka mendengarkan arahan fasilitator. Motivasi untuk mengikuti Pelatihan membaca Al-Qur'an sangat beragam, mulai dari motivasi yang sangat sederhana hingga motivasi ingin mendapatkan perubahan dalam hidupnya dan mendapat pengetahuan agama dengan bisa membaca $\mathrm{Al}$ Quran. Beragam motivasi yang melatar belakangi para peserta dalam mengikuti pelatihan, seiring dengan berlangsungnya proses pelatihan bahwa belajar membaca Al Quran tidak semata agar bisa membaca Al Quran, melainkan beban hidup terasa lebih ringan serta rasa bangga karena bisa secara langsung membaca kitab suci yang menjadi pegangan hidupnya.

\section{Ucapan Terima Kasih}

Penelitian ini bisa terlaksana berkat program "Malioboro Mengaji" tahun 2016 yang merupakan kerjasama LDPM UCY, Paguyuban Kawasan Malioboro, FLKM, LAZ al-Azhar DIY dan APKLI DIY dan bantuan pribadi yang tidak dapat disebutkan satu persatu. Para dosen dan mahasiswa FAI UCY adalah penulis sekaligus pembina dan tutor dalam program tersebut mengucapkan terima kasih atas kerja sama dan bantuannya. Meski demikian, penelitian ini tidak mencerminkan pendapat dan pandangan kelembagaan maupun pribadi dari masing-masing mitra kerja sama sehingga menjadi tanggung jawab pribadi para penulis secara penuh.

\section{Daftar Pustaka}

Ancok, Djamaludin, dan Fuat Nashori Suroso. 2005. Psikologi Islam: Solusi Islam Akan Problem Psikologi. Yogyakarta: Pustaka Pelajar.

Bisri, Mohammad. 2017. "Pengaruh Zikir Terhadap Ketenangan Dan Kebahagiaan Manusia Perspektif Qurani." Ulumuddin: Jurnal Ilmu-ilmu Keislaman 7(2):88-102.

Daradjat, Zakiyah. 2006. Pendidikan Islam Dalam Keluarga dan Sekolah. Jakarta: Ruhama.

Dister, Nico Syukur. 1982. Pengalaman dan Motivasi Beragama, Pengantar Psikologi Agama. Jakarta: LEPPENAS.

Febrianingsih, Dian, dan Arih Merdekasari. 2018. "Komitmen Beragama dalam Pendidikan Islam Berbasis Masyarakat Mahasiswa STIT Islamiyah Karya Pembangunan." al-Murabbi 11(2):66-89. 
Giussani, Luigi. 1998. "Religious Awareness in Modern Man." Communio International Catholic Review 25(1):104-40.

Hakiki, Titian, dan Rudi Cahyono. 2015. "Komitmen Beragama pada Muallaf ( Studi Kasus pada Muallaf Usia Dewasa )." Jurnal Psikologi Klinis dan Kesehatan Mental 4(1):20-28.

Hamali, Syaiful. 2017. "Sumber Agama Dalam Perspektif Psikologis." KALAM 7(1):163-82. doi: 10.24042/klm.v7i1.449.

Heri, Totong. 2019. "Pembinaan Kesadaran Beragama Sebagai Upaya Peningkatan Pemahaman Agama Islam Di Lapas Kelas Iib Anak Wanita Tangerang." Jurnal Pendidikan Islam 10(2):142-55. doi: 10.22236/jpi.v10i2.3966.

Kartini, Kartono, dan Jenny Andari. 1996. Hygine Mental, Kesehatan Mental Dalam Islam. Bandung: Mandar Maju.

Mulyadi, Mulyadi. 2015. "Perkembangan Jiwa Keberagamaan Pada Orang Dewasa Dan Lansia." Jurnal Al-Taujih: Bingkai Bimbingan dan Konseling Islami 1(1):44-55. doi: 10.15548/atj.v1i1.922.

Munirah, dan Nilda S. Ladiku. 2018. "Pengembangan Sikap Keberagamaan Peserta Didik." Jurnal Ilmiah AL-Jauhari: Jurnal Studi Islam dan Interdisipliner 4(2):336-48.

Mustafa, Mustafa. 2016. "Perkembangan Jiwa Beragama Pada Masa Dewasa." JURNAL EDUKASI: Jurnal Bimbingan Konseling 2(1):77. doi: 10.22373/je.v2i1.692.

Nasution, Harun. 1985. Islam Ditinjau Dari Berbagai Aspeknya Jilid 1. Jakarta: UI Press.

Rahayu, Supriati H., Hidayatul Huda, Joko Wahono, Difla Nadjih, dan A. Zain Sarnoto. 2019. "Implementasi Pendidikan Quran Tingkat Lanjut Bagi Santri Usia Dewasa." Nuansa Akademik Jurnal Pembangunan Masyarakat 4(1):63-78.

Rahmat, Jalaludin. 2007. Psikologi Agama. Jakarta: Mizan.

Subandi. 1995. "Perkembangan Kehidupan Beragama." Buletin Psikologi 3(1):11-18. doi: 10.22146/bpsi.13379.

Sudrajat, Ajat. n.d. Pendidikan Agama Dan Kesadaran Beragama. Yogyakarta.

Sugiyono. 2013. Metode Penelitian Kombinasi (Mixed Methods). Bandung: Alfabeta. 
Wahyu Amin Arifudin, Nurul Fatihah, Ahmad Echsan, Lailatul Naftuhah, Diila Nadjih, Agus Pandoman 